\title{
Density-governing mechanisms in populations of the lugworm Arenicola marina on tidal flats
}

\author{
E. C. Flach, J. J. Beukema \\ Netherlands Institute for Sea Research, PO Box 59, 1790 AB Den Burg, Texel, The Netherlands
}

\begin{abstract}
Population densities of lugworms Arenicola manina on tidal flats are remarkably stable and even. In the Dutch Wadden Sea and on the Swedish west coast, we studied processes which might explain the low variability in time and space in lugworms. Local enhancement of densities resulted in a return to original (and surrounding) densities within 1 yr. Juveniles settled mainly in areas with low adult densities. This was so both in natural areas and in experimental plots with either enhanced or reduced adult densities. Only some of the natural areas with low adult and high juvenile densities had the special environmental conditions of the so-called Brutwatten or nursery areas. Juveniles were smaller in areas where their densities were high than where their densities were low. Short periods of juvenile migration in winter reduced the locally high densities of small juveniles. Recruitment of juveniles was higher in years with low than with high mean densities of adults. We consider the roles of lugworm bioturbation and food limitation in controlling lugworm densities.
\end{abstract}

KEY WORDS: Population density $\cdot$ Regulation $\cdot$ Density dependent $\cdot$ Adult-juvenile interactions $\cdot$ Bioturbation effects - Arenicola - Tidal flat

\section{INTRODUCTION}

The lugworm Arenicola marina (L.) is a dominant member of the tidal-flat fauna of the Wadden Sea, accounting for 10 to $20 \%$ of the benthic biomass in many areas (Beukema 1976, Dörjes et al. 1986). Lugworms are present in all tidal flat areas where environmental conditions such as sediment composition and intertidal level are not too extreme (Beukema \& de Vlas 1979, Dankers \& Beukema 1983). Of 99 transects sampled all over the Dutch Wadden Sea, no less than 85 had lugworms (Beukema 1976). Intensive bioturbation (Cadée 1976) associated with the burrowing and feeding activities of lugworms can significantly affect the abundance of other infaunal species (Reise 1985, Brey 1989, Flach 1992, 1993).

Lugworms differ from nearly all other tidal-flat species in the relative stability of their abundance (Reise 1985). On Balgzand (The Netherlands), the 24 annual (1970 to 1993) estimates of mean late-winter density were all within the limited range of 14 to $36 \mathrm{~m}^{-2}$, while biomass values were all between 3 and $7 \mathrm{~g}$ ash-free dry weight $\mathrm{m}^{-2}$ (Beukema 1992). None of the 20 other species regularly occurring in the same area shows so little year-to-year variation (Beukema et al. 1993). Moreover, the distribution of lugworms over the tidal flats is remarkably even (Beukema et al. 1983).

A species that shows a notable constancy (in time) and evenness (in space) is a promising object for a study of feed-back mechanisms such as territorial behaviour (promoting spacing-out) and negative density dependence of such processes as recruitment, survival and migration (restricting the occurrence of extremely high or low numbers). So far, evidence for density-dependent control of numbers in populations of members of marine soft-bottom communities appears to be rare.

To study a possible spacing-out mechanism, we enhanced densities of adults in experimental plots and followed changes in these densities during subsequent months. Along several long transects (both in the Wadden Sea and on the west coast of Sweden), we compared the distributions of adults and juveniles to test whether the presence of adults affected the settlement of juveniles. Changes in densities of juveniles were followed in plots with enhanced and reduced numbers 


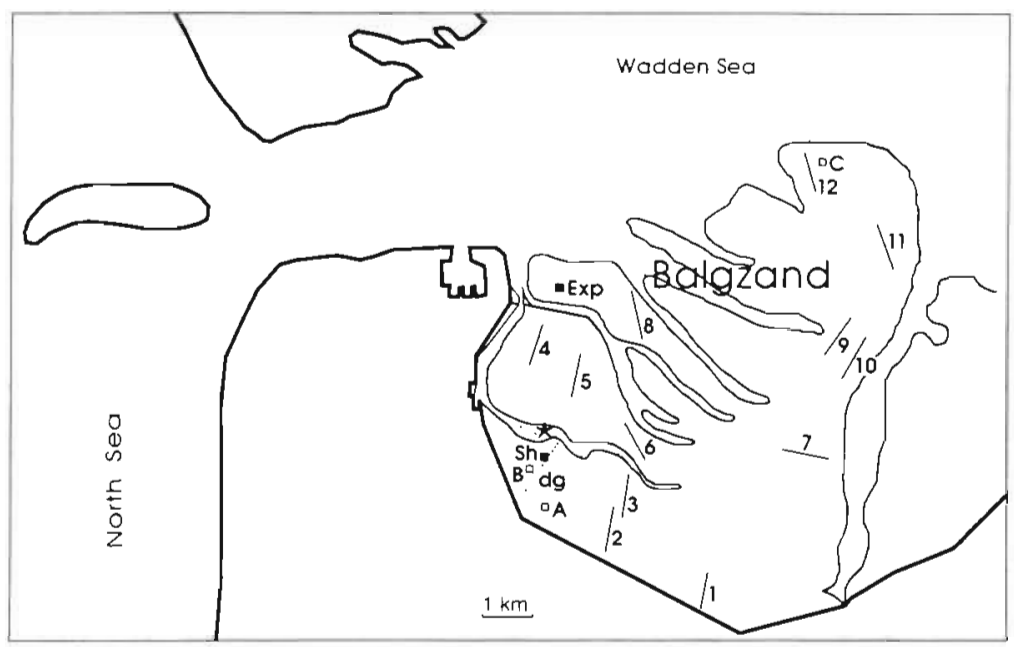

Fig. 1. Balgzand, Dutch Wadden Sea, showing the locations of the transects $\left(1-12, \mathrm{dg}^{\prime}\right)$, regularly sampled Stations (A to C) and sites where the experiments were performed ('Exp', 'Sh'). The fishing location is indicated by * The approximate borders of the tidal flats at LLWS are shown. Mean tidal range is $140 \mathrm{~cm}$. The sediment is silty along the mainland coast, becoming gradually sandier at increasing distance from the coast

of adults. The availability of a set of long-term data on numbers of macrobenthic animals enabled us to relate annual lugworm recruitment to adult densities.

\section{METHODS}

Surveys. At Balgzand (Fig. 1), a $50 \mathrm{~km}^{2}$ tidal-flat area in the westernmost part of the Wadden Sea, 12 transects (numbered 1 to 12 ) of $1 \mathrm{~km}$ each and 3 square sampling stations ( $A, B$, and $C$ ) of $900 \mathrm{~m}^{2}$ each were sampled quantitatively twice a year from 1970 to 1993. Details on sampling procedures can be found in earlier papers (e.g. Beukema 1974, 1993b). In brief, cores were taken and sieved $(1 \mathrm{~mm})$ in the field and sorted in the laboratory. Numbers of both adult and juvenile lugworms are expressed per $\mathrm{m}^{2}$ (total area sampled was $13.5 \mathrm{~m}^{2}$ in March and $6.5 \mathrm{~m}^{2}$ in August), and biomass values in $\mathrm{g}$ ash-free dry weight (AFDW) per $\mathrm{m}^{2}$. Macrobenthic fauna and environmental conditions of Balgzand are described in Beukema (1988).

For 3 years (1990, 1991, and 1992) lugworm densities were estimated in detail along one transect (' $\mathrm{dg}^{\prime}$ in Fig. 1) perpendicular to the shore, by counting every $20 \mathrm{~m}$ the casts from both adult and juvenile lugworms in plots of $1 \mathrm{~m}^{2}$ each. We checked this counting method by comparing such numbers with those found by sieving the same $0.1 \mathrm{~m}^{2}$ plots. On average, the cast counts were $6 \%$ lower than the numbers found by sieving (Fig. 2). Farke et al. (1979) observed a similar underestimation by $\sim 6 \%$ of the density by cast counts in adult and juvenile lugworms. The clear difference between adult and juvenile casts makes it an easy and quite reliable method to determine abundance and distribution patterns over extensive areas (Farke et al. 1979).

In 4 places along this transect, samples of $0.4 \mathrm{~m}^{2}$ were dug to determine the individual weights (AFDW) of the juvenile lugworms in November 1991 and at the end of January 1992.

In summer 1991, lugworm casts were also counted in $1 \mathrm{~m}^{2}$ plots every $50 \mathrm{~m}$ along several transects of $1 \mathrm{~km}$ perpendicular to the shore at other places in the Dutch Wadden Sea. The locations and the sediment composition along these transects are given in Flach (1993).

In a small, shallow bay (Finnsboviken, water depth 0 to $0.7 \mathrm{~m}$ ) along Gullmarsfjorden, western Sweden (detailed information given in Flach \& de Bruin 1993), lugworm populations were followed during summer in both 1992 and 1993. Lugworm densities (adults and juveniles separately) were estimated by counting the casts in $1 \mathrm{~m}^{2}$ plots along a transect perpendicular to the shore and also along a transect parallel with and close to the lowwater line. Because the tidal range in Gullmarsfjorden is only about $20 \mathrm{~cm}$, the width of the intertidal zone is only $\sim 100 \mathrm{~m}$ and therefore distances between the samples were only $10 \mathrm{~m}$. The sediment composition along the transects was similar with a proportion of silt $(<50 \mu \mathrm{m})$ of $-2 \%$.

Experiments. In 2 different sites in the Balgzand area ('Exp' exposed and sandy, 'Sh': sheltered with an intermediate sediment; Fig. 1) lugworm densities were manipulated in small plots of $2.25 \mathrm{~m}^{2}$ to obtain densi-

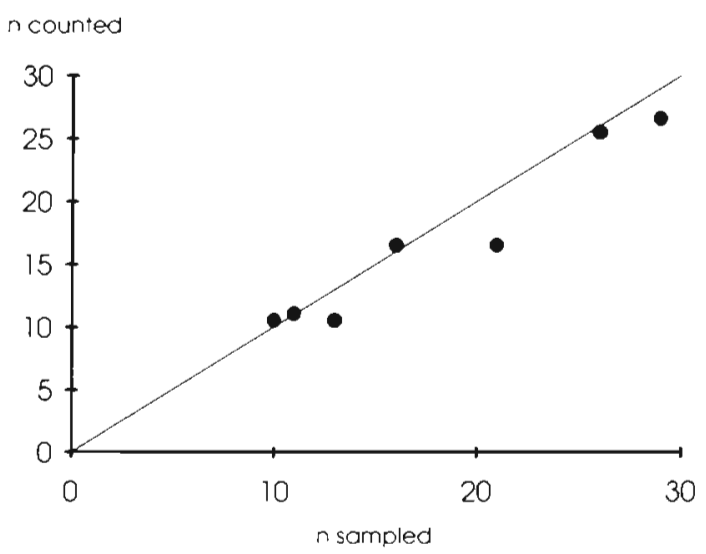

Fig. 2. Arenicola marina. Relationship between numbers of juvenile lugworms caught by sieving $0.1 \mathrm{~m}^{2}$ plots and numbers of casts counted before sieving, in November 1991. The Line indicates equal numbers 
ties of $0,25,50,75$, and 100 adults $\mathrm{m}^{-2}$ (all densities in duplicate) in April 1990. Lugworm densities in these small plots were followed by counting the casts for 1 yr (until March 1991) and compared to the natural lugworm density at these sites. In April 1991, the plots were restocked to obtain the initial densities of 0,25 , 50,75 , and $100 \mathrm{~m}^{-2}$. In 1991 the settlement of juvenile lugworms was studied in these small plots with different densities of adults by counting the casts of both adults and juveniles during the summer and autumn (viz. in June, July, August, September, and October). In November 1991, samples of $0.4 \mathrm{~m}^{2}$ were taken from all small plots at Site Sh to determine the individual weights (AFDW) and the exact densities of the juvenile lugworms.

In Finnsboviken, experiments were carried out at 3 different depths (immersion periods 8, 12, and $18 \mathrm{~h}$ per day). Densities of adult lugworms were either enhanced or diminished in small $1 \mathrm{~m}^{2}$ plots to densities of 0,50 , and $100 \mathrm{~m}^{-2}$ (all densities in duplicate) at all 3 sites in April 1992. In June the numbers of settled juveniles in these plots were counted and compared to the natural densities at these depths.

In 1992, an experiment was carried out at Balgzand (Site Sh) to see whether it would be possible to maintain artificially enhanced densities by repeated restocking in the same places. The experiment lasted from March to June; the lugworm casts were counted 3 times (after each $30 \mathrm{~d}$ period) and restocked to the initial densities of $25,50,75$, and $100 \mathrm{~m}^{-2}$. The experiment was performed in duplicate, thus yielding for each density treatment 6 observations on density change. At the same time the natural lugworm densities were estimated around the plots.

Fishing. As Beukema \& de Vlas (1979) also caught small lugworms during the winter while fishing for bivalves (juvenile Macoma), we fished, from November 1991 until February 1992, in the main tidal channel close to Transect dg ( $\star$ in Fig. 1). We used the method of passive fishing described by Beukema \& de Vlas (1979) with a net with an opening of $1 \mathrm{~m}^{2}$ and $1 \mathrm{~mm}$ mesh width behind an anchored vessel. We only fished during ebb tides. A fishing day consisted of 3 netting periods of $20 \mathrm{~min}$ each.

\section{RESULTS}

\section{Spatial variation}

Distribution patterns on a small scale

Within the $30 \times 30 \mathrm{~m}$ squares on Balgzand, Iugworms generally showed an over-dispersed distribution pattern. On nearly all sampling occasions, the variance

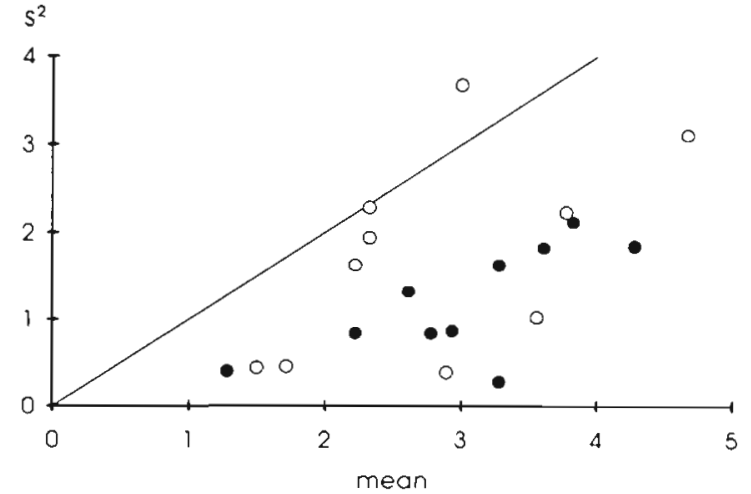

Fig. 3. Arenicola marina. Relationship between variance $\left(s^{2}\right)$ and mean of 20 twice-annual estimates (from 9 samples of $0.1 \mathrm{~m}^{2}$ each) of lugworm density at Station B on Balgzand (see Fig. 1). The line of $s^{2}=$ mean is drawn. (•) Summer;

(O) winter estimates

was lower than the mean of the 9 samples of $0.1 \mathrm{~m}^{2}$ taken within such $900 \mathrm{~m}^{2}$ squares. As an example, Fig. 3 shows the paired values of mean and variance observed at twice-annual sampling over the last $10 \mathrm{yr}$ (1984 to 1993) in one of the 3 permanent squares on Balgzand (for obvious reasons, we chose the one where we found the broadest range of densities). In 19 out of the 20 cases, the variance $s^{2}$ was smaller than the mean $\bar{x}$ ( $p<0.001$, ranked-signs matched-pairs test). Only sometimes in late winter were $s^{2}$ values close to $\bar{x}$ values, pointing to more or less random distribution patterns within the $900 \mathrm{~m}^{2}$ squares. In summer, all s values were well below $\bar{x}$, pointing to a more even than random pattern of distribution at this scale. Patterns in winter appeared to be less consistent than in summer. Indeed, summer values of the variance/mean quotients showed less variation than late-winter values $(\mathrm{p}<0.01, F$-test).

Experiments with locally $\left(2.25 \mathrm{~m}^{2}\right.$ plots $)$ enhanced densities showed rapid decline of such high densities to the level of the densities of the surrounding area (where densities hardly changed during the period of observation). Fig. 4 shows the declining numbers observed at Site Exp at Balgzand. After 1 yr, densities had returned to the natural density of $\sim 10 \mathrm{~m}^{-2}$ in nearly all plots. Similar changes in lugworm densities were observed at Site Sh (see Fig. 3b of Flach 1992). In this square all densities declined in the course of 1 yr to $-20 \mathrm{~m}^{-2}$, the natural density at this site

Initial declines appear to have been steeper when starting from extremely high than from close-to-natural densities (Fig. 4). Rates of decline were studied in more detail in a separate experiment by replacing the worms that had disappeared, after 1 mo. These rates were indeed higher when starting from high than from lower initial densities. Monthly declines amounted to 


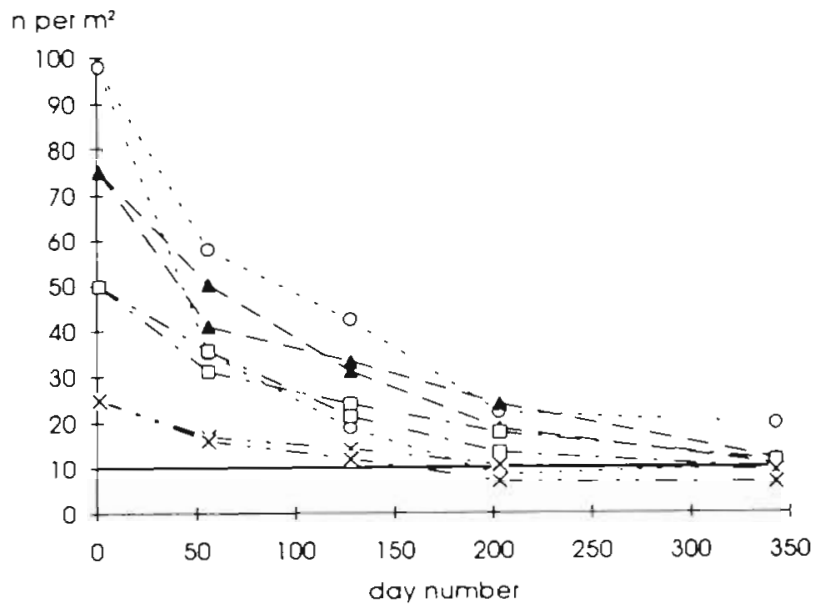

Fig. 4. Arenicola marina. Decreases of artificially enhanced densities of adult lugworms in 8 plots within Site Exp at Balgzand (see Fig. 1). Different symbols denote different initial densities (indicated by the points on the vertical axis). Within 1 yr all densities were close to the naturally occurring density in the surrounding area (solid line)

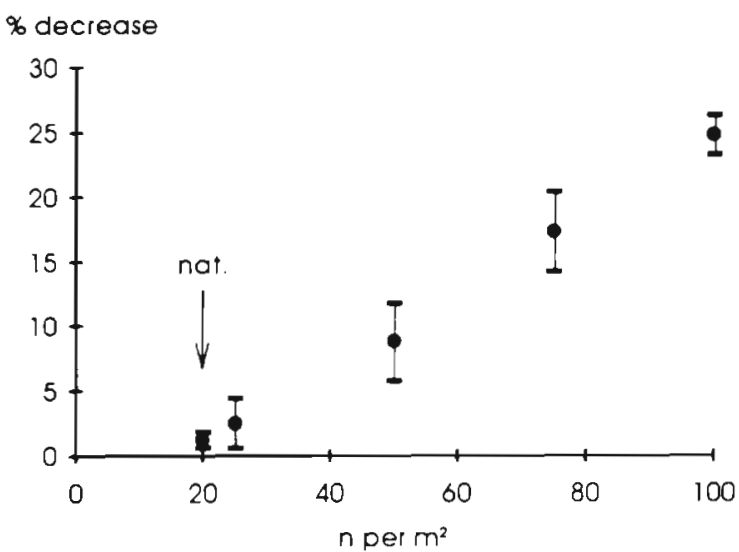

Fig. 5. Arenicola marina. Proportional decrease (\% of initial density, with $1 \mathrm{SE}, \mathrm{n}=6$ ) in artificially enhanced densities accomplished in $30 \mathrm{~d}$ periods in $2.25 \mathrm{~m}^{2}$ plots. In the naturally occurring density $\left(\sim 20 \mathrm{~m}^{-2}\right)$ little variation (on average only $-1 \%$ ) was found within these periods

about $25 \%$ of densities that were several times higher than the natural densities, but were only about $10 \%$ per month if densities were doubled (Fig. 5). The 3 differences in the decline rates between the 4 initial artificially enhanced densities were statistically significant ( $\mathrm{p}<0.05$, Wilcoxon-Mann-Whitney test) .

\section{Juvenile settlement}

Juvenile lugworms settled mainly in areas with low adult densities. Along transects perpendicular to the coasts of 3 West Frisian islands, high numbers of adults
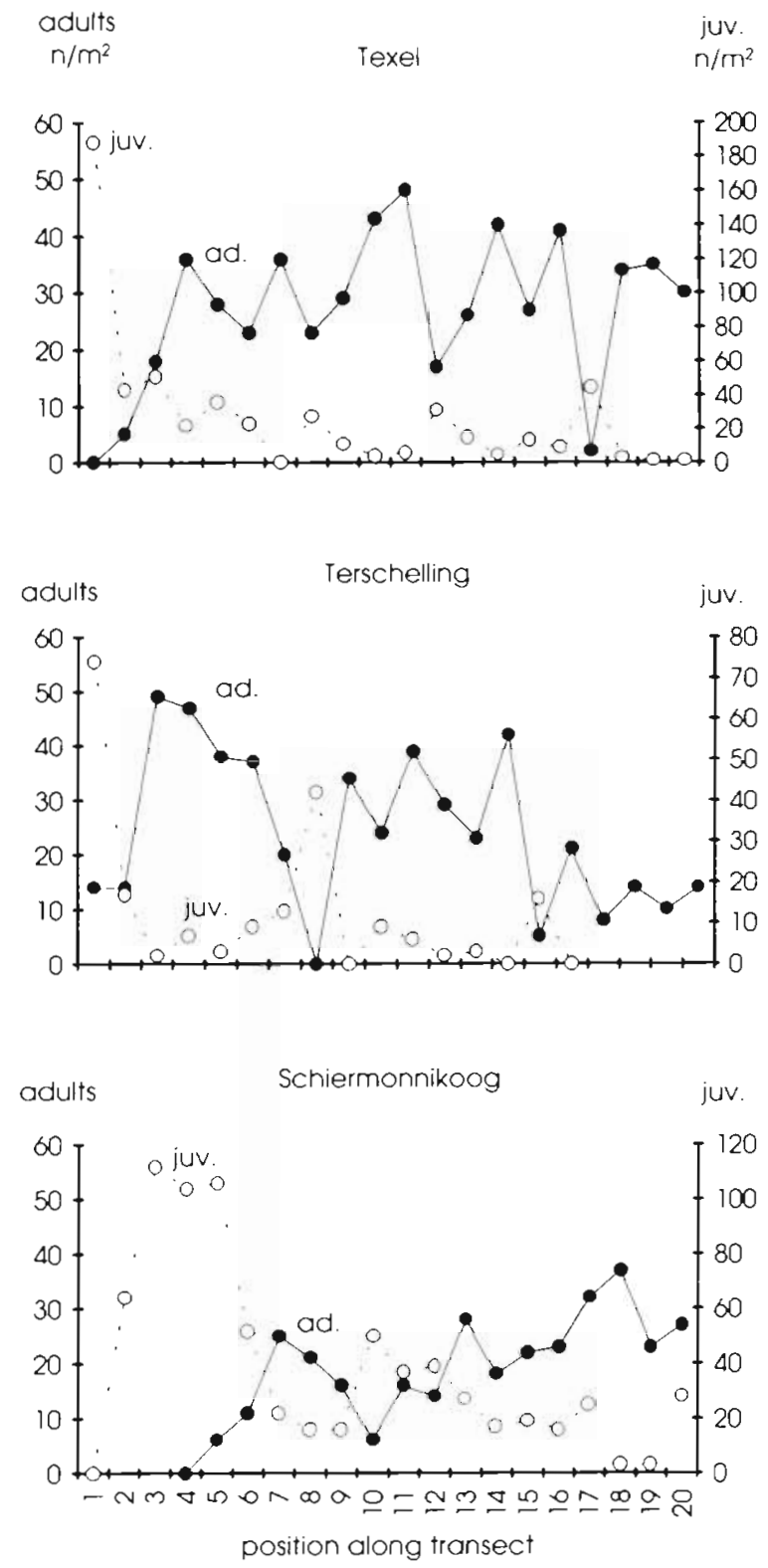

Fig. 6. Arenicola marina. Densities $\left(\mathrm{n} \mathrm{m}^{-2}\right)$ of adult $(\bullet \bullet)$ and juvenile $(0 \cdots O)$ lugworms along transects perpendicular to the shore in 3 different parts of the Dutch Wadden Sea in July 1991. Position 1 is close to the shore; the distances between the samples were $50 \mathrm{~m}$. Note the difference in scale for adults and juveniles

and juveniles showed a clearly alternating pattern: generally the numbers of juveniles were high only where adult numbers were low (Fig. 6). In particular a near-coastal zone was characterised by very high densities of juveniles (around $100 \mathrm{~m}^{-2}$ in 1991) and lowerthan-average densities of adults. Such coastal zones have been described as nurseries (Brutwatten or Junggutwatt) by Thamdrup (1935), Smidt (1951), Werner (1956), and Farke et al. (1979) for the Wadden Sea and 
by Cazaux (1967) and Pollack (1979) for similar areas along the French coast. Note that the occurrence of juveniles was not restricted to these zones. Juvenile densities could exceed those of adults at various places, often far from the coast, e.g. at Position 8 along the Terschelling transect and at Position 10 along the Schiermonnikoog transect.

Density changes along one transect (dg) were followed in some detail on Balgzand during 1990 to 1992 (Fig. 7). At the start of the observations in May 1990 (Fig. 7a) only adults were present. They showed the usual pattern on Balgzand with low densities in a high and silty coastal zone and higher densities in lower zones with rather sandy sediments. Half a year later, adult densities had declined, especially in the middle part of the transect around the Positions 20 to 30 (Fig. 7b). In May 1991, juveniles were also present. In comparison with former years, their numbers were high. They were particularly numerous in the area where adult numbers had declined most during the foregoing year, around Position 25 (Fig. $7 \mathrm{C}$ ). In October 1991, the inverse distribution pattern of adults and juveniles was even clearer (Fig. 7d). In July 1992 (Fig. 7e) the juveniles of 1991 had reached adult size. At this time, the original pattern of adult distribution depicted in Fig. $7 \mathrm{a}$ was restored. The new generation of juveniles again inhabited areas with low adult densities (Fig. 7 e), but such areas were now found in other parts of the transect than in the foregoing year (compare Fig. $7 \mathrm{c}$, d with Fig. 7e). Apparently, there is no permanent zone for juvenile recruitment on Balgzand. Lugworm recruits appear to settle successfully everywhere in the upper half of the intertidal where the sediment is not too silty and adult densities happen to be low.

In Finnsboviken, similar patterns of alternatingly high densities of adults and juveniles were observed (Fig. 8). In this Swedish bay, a zone with high adult densities was present in the middle part of the transect in 1992. High densities of juveniles were found at both the landward and the seaward margins of this zone (Fig. 8a). In 1993, however, the zone with high adult densities had shifted to the shore and juveniles were only found in high densities at the seaward side (Fig. 8b). As observed on Balgzand, the near-absence of adults appears to be more important for successful recruitment of juvenile lugworms than the exact inter-

Fig. 7. Arenicola marina. Densities $\left(\mathrm{n} \mathrm{m}^{-2}\right)$ of adult $(\bullet-)$ and juvenile $(0-\cdots)$ ) lugworms along Transect dg at Balgzand on a series of dates in 1990 to 1992: (a) May 1990, (b) October 1990, (c) May 1991, (d) October 1991, and (e) July 1992. Position 1 is close to the shore, between Positions 9 and 10 a small channel occurred. The distance between the samples was $20 \mathrm{~m}$. Note the difference in scale for adults and juveniles
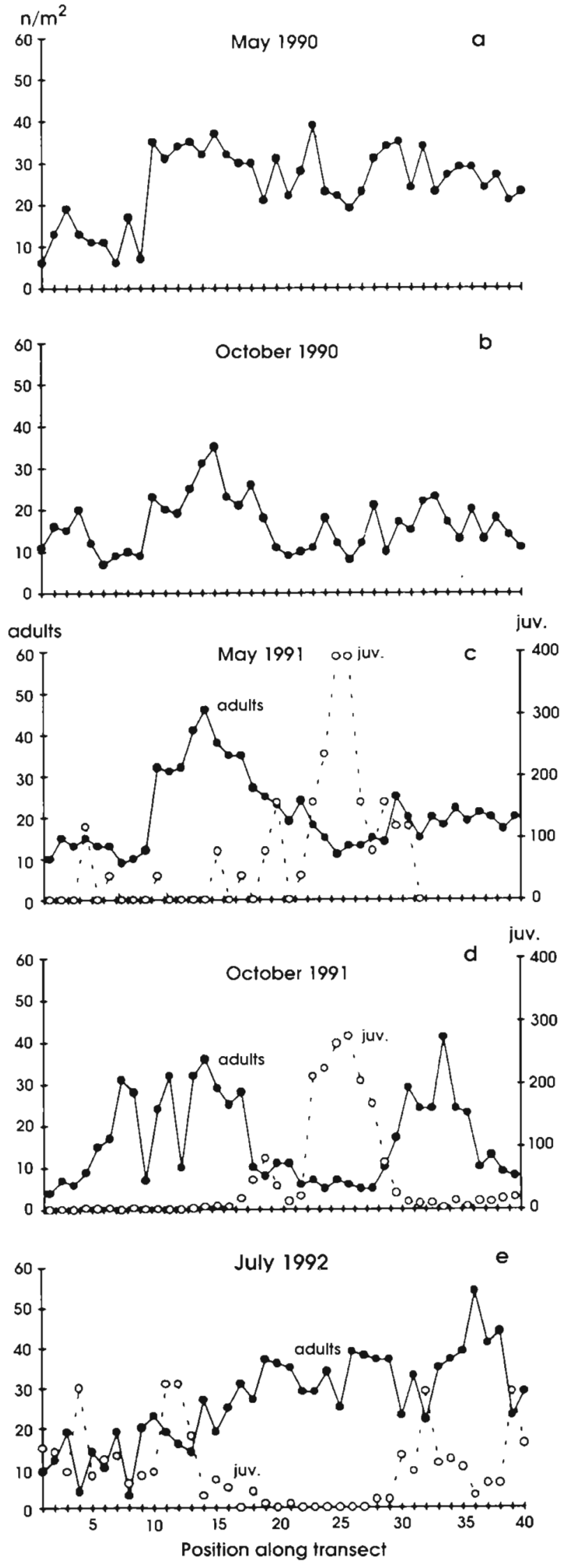


\section{Finnsbovik}

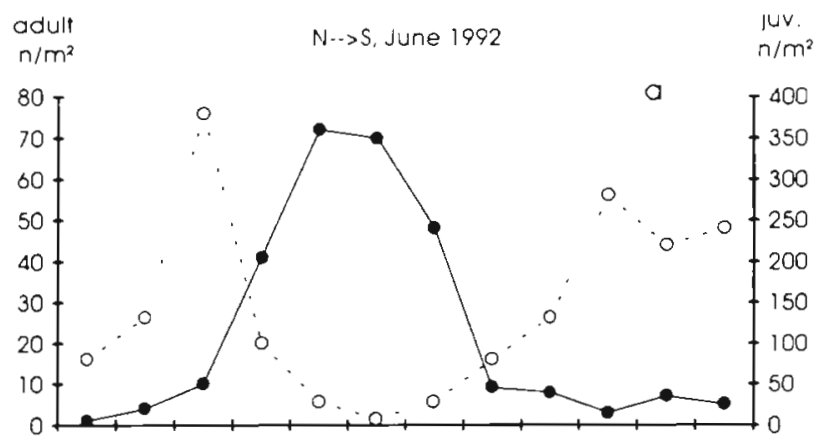

$N->S$, June 1993

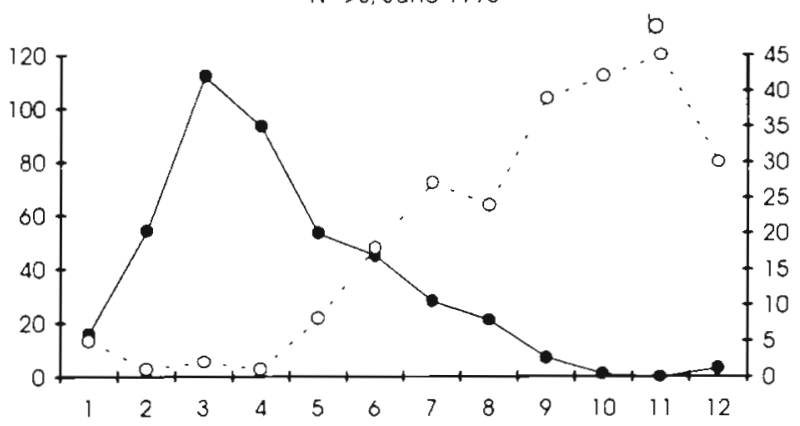

W->E, June 1992

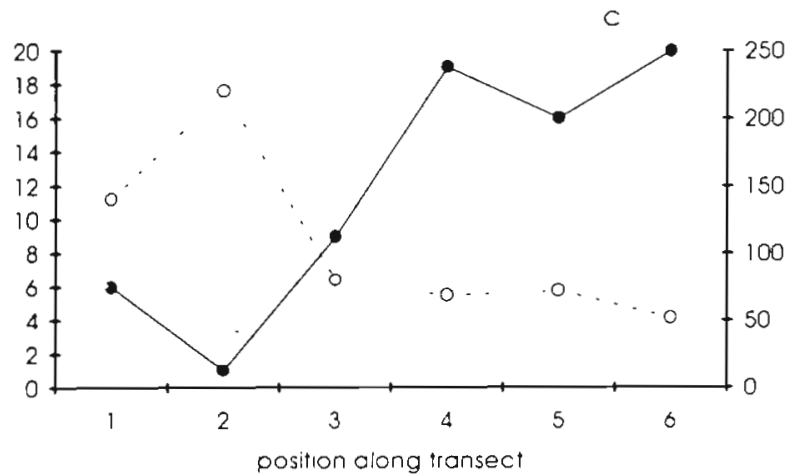

Fig. 8. Arenicola marina. Densities $\left(\mathrm{n} \mathrm{m}^{-2}\right)$ of adult $(--)$ and juvenile $(0 \cdots 0)$ lugworms along transects perpendicular to $(a, b)$ and parallel with (c) the shore in Finnsboviken, western Sweden. Position 1 in (a) and (b) is close to the shore and Position 3 in (c) is the same spot as Position 8 in (a). The distance between the samples was $10 \mathrm{~m}$

tidal level. Densities of adults and juveniles observed along a transect running parallel to the low-water line (Fig. 8c) again showed an inverse distribution pattern of the 2 age groups, regardless of intertidal level.

Experimental plots where the densities of adult lugworms were artificially enhanced or reduced in early spring showed differential densities of juveniles in summer and autumn: the higher the densities of adults,
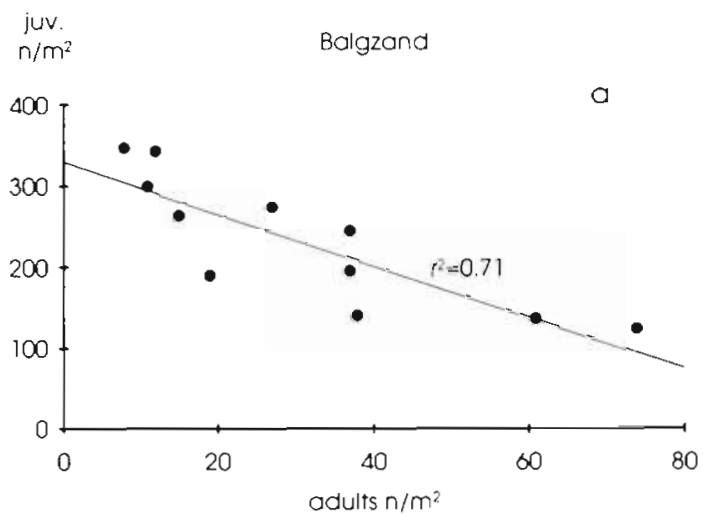
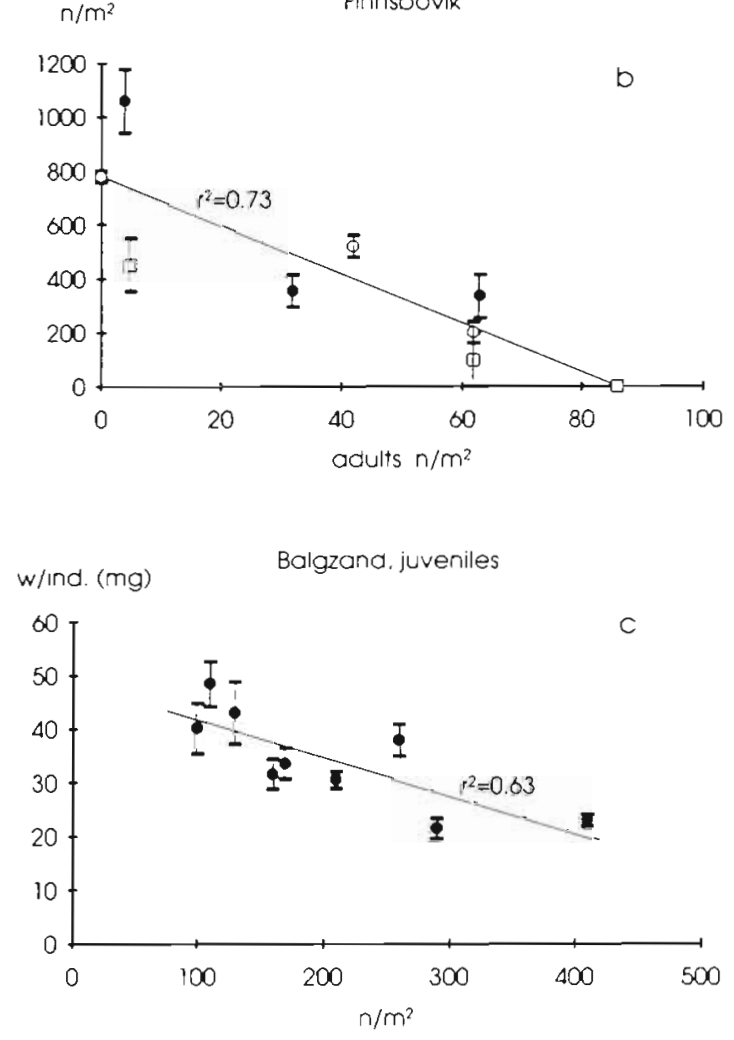

Fig. 9. Arenicola marina. Relationship between densities (n $\mathrm{m}^{-2}$ ) of adult and juvenile lugworms in small experimental plots: (a) within Site Sh at Balgzand in 1991, and (b) at 3 different depths in Finnsboviken in 1992. Adult densities were manipulated in spring (April); juvenile densities were estimated in summer (in July at Balgzand and in June in Finnsboviken). Natural densities of adults amounted to $20 \mathrm{~m}^{2}$ at Balgzand and to $4 \mathrm{~m}^{-2}$ at the shallow Position $1(\bullet), 42 \mathrm{~m}^{-2}$ at Position $2(0)$ and $62 \mathrm{~m}^{-2}$ at Position $3(\square)$ in Finnsboviken. (c) Relationship between the density and the mean individual weights (mg AFDW $\pm \mathrm{SE}$ ) of the juveniles in the various small plots within Site Sh at Balgzand

the lower were the numbers of juveniles. Negative relationships between densities of adults and juveniles were found both on Balgzand (Fig. 9a: $r=-0.84, n=12$, 
$\mathrm{p}<0.01$; July estimates) and in Finnsboviken (Fig. 9b: $\mathrm{r}=-0.85, \mathrm{n}=9, \mathrm{p}<0.01$; June estimates). Local additions of adult lugworms to naturally low densities (as in Position 1 in Finnsboviken) resulted in reduced densities of juveniles (solid points in Fig. 9b), whereas local thinning of adult stocks (as in Positions 2 and 3 in Finnsboviken) resulted in increased densities of juveniles (2 types of open symbols in Fig. 9b).

At Balgzand, estimates of juvenile densities in all summer and autumn months yielded essentially the same results. Thus, from June on (or possibly even earlier), the juvenile densities showed the negative relationship with adult densities shown in Fig. 9a. Apparently, juvenile densities adapt to adult densities early in summer, avoiding areas where adults are crowded and settling mainly in areas where empty space is available.

Although the numbers of juveniles were low in the plots with high adult densities, their individual weights were higher than in the plots with high juvenile densities (Fig. 9c: $r=-0.79, n=9, p<0.05$ ). This relationship might suggest either that juvenile growth is affected by the presence of other lugworms (in a negative way by other juveniles and/or in a positive way by adults) or that small juveniles are more inclined than large ones to leave areas already occupied by adults. We studied the latter possibility by fishing for migrating lugworms in a nearby tidal stream.

\section{Juvenile migration}

The life cycle of lugworms is rather intricate. They inhabit a number of habitats in succession (Farke \& Berghuis 1979a, b, Reise 1985). In spring, postlarvae of 4 to $9 \mathrm{~mm}$ are present in the plankton of the Wadden Sea (Farke \& Berghuis 1979b). Throughout spring and early summer, these postlarvae settle on the tidal flats of the Wadden Sea (Farke \& Berghuis 1979b). Then the well-known benthic life in J-shaped burrows begins. During spring and summer the juveniles grow from a size of about $1 \mathrm{~cm}$ to about $5 \mathrm{~cm}$, reaching a weight of a few to several tens of $\mathrm{mg}$, up to about $100 \mathrm{mg}$ AFDW. Not until their second summer do they reach adult size and weight (several hundreds to a few thousands of mg AFDW). During all of their benthic life, they frequently change position, mainly by moving for short distances through the sediment.

At the end of their first full year of life, some juveniles show a true long-distance migration by leaving their burrows and swimming in the water (Werner 1956, Beukema \& de Vlas 1979). Our observations in $1991 / 1992$ corroborated that juveniles are present in the water around tidal flats particularly in winter. Cold periods appear to stimulate this migration (as also sug-
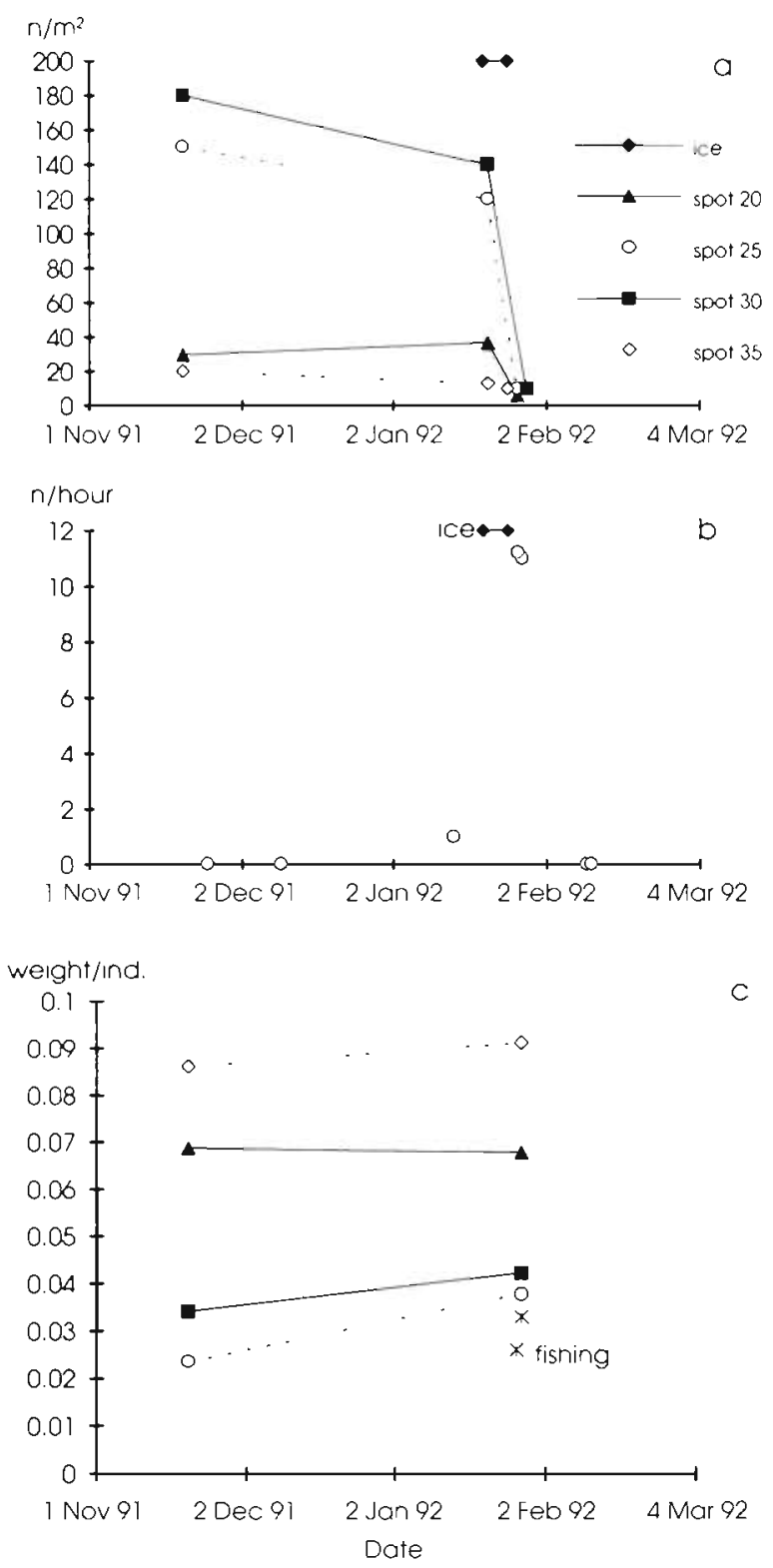

Fig. 10. Arenicola marina. (a) Densities $\left(\mathrm{n} \mathrm{m}^{-2}\right)$ of juvenile lugworms at 4 positions along Transect dg during winter 1991-1992 (sampling dates: 20 November, 21 and 28 January). (b) Results of fishing in the nearby tidal channel during that winter: juvenile lugworms were caught only in January, especially shortly after the indicated ice period (27-28 January). (c) Individual mean weights (g AFDW) of the juveniles as estimated on 20 November and 28 January at the 4 positions along the transect [Positions as in (a)] and of the juveniles caught on 27 and 28 January in the tidal channel $(x)$

gested by Werner 1956), as high lugworm numbers were only caught shortly after an ice period (Fig. 10b). At the same time the numbers of juveniles on the tidal flats decreased dramatically (after they had been nearly constant for a long period), particularly in the places where their densities were relatively high 
(Fig. 10a). At the 2 stations with the highest densities (Positions 25 and 30 situated within the area of high juvenile abundance; see Fig. 7 d), the declines amounted to 92 and $93 \%$, whereas these declines were 84 and $23 \%$ at the lower initial densities (Positions 20 and 35 , respectively, outside the area of high juvenile densities)

In comparison with the huge numbers disappearing from the transect in late January, we caught only relatively small numbers during the ebb in the tidal channel. Only an estimated $5 \%$ of the lugworms that had disappeared turned out to have been transported by the tidal stream at the fishing station. However, we fished only during daylight hours. As in postlarval lugworms (Farke \& Berghuis 1979), juveniles may migrate mainly during the night and we may have grossly underestimated tidal-current transport.

Nearly all migrating lugworms caught in the tidal streams of Balgzand were of juvenile size. The mean weight $( \pm \mathrm{SD})$ of these juveniles was $31.2 \pm 16.0 \mathrm{mg}$ AFDW. No adults were caught, since all individuals weighed less than $90 \mathrm{mg}$. The mean weights of the swimming juveniles were significantly $(p<0.05$, Wilcoxon-Mann-Whitney test) lower than those of the populations living simultaneously on most of the nearby tidal flats (Fig. 10c).

If especially the smaller juveniles left these tidal flats, mean weights of remaining juveniles should increase during the period of migration in winter. A significant ( $p<0.05$, Wilcoxon-Mann-Whitney test) increase in weight was indeed observed in the area where (the high) juvenile densities dropped most rapidly in January (Fig. 10c: Positions 25 and 30 as contrasted to Positions 20 and 35, where relatively few juveniles left) Before the migration started, the juveniles were relatively small in the high-density area: 20 to $40 \mathrm{mg}$ as opposed to 60 to $100 \mathrm{mg}$ along other parts of the transect where juvenile densities were lower in late 1991 (Fig. 10c). Thus, the winter migrants originated mainly from areas where the juveniles were relatively small and crowded and from these areas particularly the smaller individuals emigrated.

\section{Annual variation in recruitment}

Long-term data on densities of adults and juveniles are available for Balgzand from samplings in late winter during all years from 1970 to 1993 and from samplings in summer from 1980 to 1993. Generally, mean densities in late winter were hardly lower than those observed in the foregoing summer, although the winter migration had taken place in between. However, in a year with exceptionally high densities of juveniles (summer 1991), the reduction was much
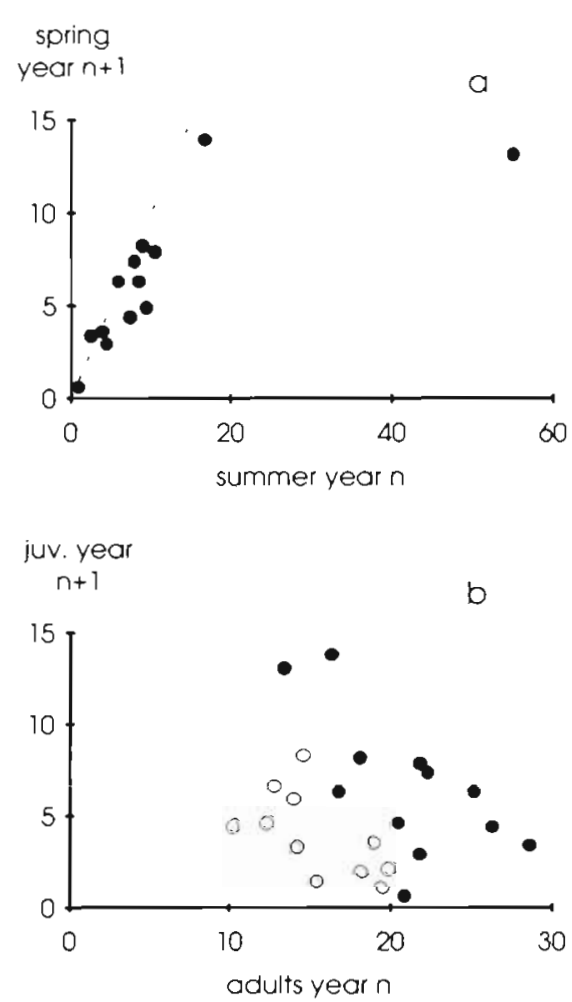

Fig. 11. Arenicola marina. Long-term data on recruitment of lugworms on Balgzand: average densities $\left(\mathrm{n} \mathrm{m}^{-2}\right)$ of 15 stations sampled in March (1970 to 1993) and August (1980 to 1993). (a) Relationship between mean densities of juveniles observed in August and half a year later in early spring; (b) relationship between mean densities of adults in early spring and those of juveniles 1 yr later, separately for 2 periods: (O) 1970 to 1980 and (1) 1981 to 1993

stronger (Fig. 11a). A much higher than usual proportion of the juvenile population disappeared from Balgzand between August and March in the year with the larger-than-usual population.

If juveniles thrive only in locations with low adult densities (see above), years with low adult densities will be more favourable for juveniles than years with high adult abundance, when fewer suitable places for juveniles would be available. Fig. $11 \mathrm{~b}$ shows the expected relationship between annual estimates of adult density in late winter and annual values of den-

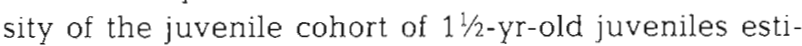
mated 1 yr later, after juveniles have stayed among the adults for almost 1 yr. Because the Balgzand benthos in the 1970 s differed strongly from that in the later years (Beukema 1991), we show this relationship separately for these 2 periods. For each separate period, the observed relationship between numbers of adults and surviving juveniles showed the expected negative correlation: $r=-0.64(n=11)$ and $r=-0.58(n=12)$, respectively (both $p<0.05$, Spearman test). The num- 
bers of juveniles were elevated after 1980 (solid symbols) as compared to the 1970 s (open symbols in Fig. 11b). Such differences were observed in several macrozoobenthic species, probably because of better feeding conditions caused by eutrophication after the 1970s (Beukema \& Cadée 1986, Beukema 1991).

\section{DISCUSSION}

Lugworms are able to exert some influence on their neighbours: they space out (Figs. $3 \& 4$ ) and move earlier, the shorter the mutual distances are (Fig. 5). Juveniles appear to be even more susceptible than adults to the nearby presence of adults, as high densities of juveniles were observed only where adults were scarce (Figs, 6, 7, 8 \& 9a, b; see also Farke et al. 1979). Some kind of intolerance effectively prevents high local densities of adults in this species. Densities of adults higher than about $100 \mathrm{~m}^{-2}$ have rarely been reported (Beukema 1976, Dankers \& Beukema 1983, Dörjes et al. 1986).

The mechanism by which adult lugworms exert a negative influence on the numbers of their congeners will be the intensive bioturbatic activities connected with their feeding behaviour. At the frequently occurring densities of some tens of adults per $\mathrm{m}^{2}$, lugworms turn over the total upper sediment layer (to a depth of a few decimeters) within 1 yr (Cadée 1976). Such negative effects of the presence of adult lugworms on the densities of other benthic organisms are not limited to con-specifics, but include (particularly the juveniles of) a large number of other species within the benthic community (Brey 1989, Flach 1992). A detailed study of the influence of lugworms on the amphipods Corophium volutator and C. arenarium by Flach (1993) and Flach \& de Bruin (1993) showed that sediment-disturbing objects, such as moving cockles and feeding lugworms, destroy the constructions of tube-building animals and chase away smaller animals. The expelled Corophium individuals swam away and settled elsewhere after some time. Meanwhile they were frequently captured by epibenthic predators (Flach \& de Bruin 1994). There is no evidence for other ways adult lugworms can reduce the numbers of their own juveniles or other species.

Juvenile lugworms appear to be more mobile than adults. Juvenile densities can rapidly decline in winter during periods of migration via tidal currents (Fig. 10a), transporting high numbers of juveniles (Fig. 10b), but only few adults (Beukema \& de Vlas 1979). Areas depleted of adults by mechanical harvesting were rapidly repopulated by juveniles but not by adults (Van den Heiligenberg 1987). Changes in adult densities were only slow (Figs. $4 \& 5$ ).
The function of spacing-out and prevention of high densities may have to do with avoidance of competition for food. Lugworms are typical deposit feeders, taking food from a limited area around their head shafts (Rijken 1979). Deposit feeders need spacing out more than suspension feeders (Levinton 1972). Indeed, among the benthic community living on tidal flats of the Wadden Sea, deposit feeders showed generally more dispersed distribution patterns than the often clustered suspension feeders (Beukema et al. 1983).

There is some evidence that both growth rates and numbers of lugworms in the Wadden Sea are limited by food. In an indoor mud flat with favourable feeding conditions, De Wilde \& Berghuis (1979) observed faster growth in juvenile lugworms than on the tidal flats of the Wadden Sea. Moreover, growth in these experiments was more rapid at low than at high densities. They attribute the retarded growth in natural populations on mud flats to insufficient food supply. During the recent period of eutrophication, when food supply to herbivores roughly doubled (Beukema \& Cadée 1986), numbers and biomass values were significantly higher than before 1980 for several macrozoobenthic species, including lugworms (Beukema 1991, 1992). The higher adult densities in recent years appear to be caused by greater survival of recruits at the same adult densities (Fig. 11b).

Both before and during the eutrophication period, recruitment of juveniles was greater at low than at high adult abundance (Fig. $11 \mathrm{~b}$ ). This negative feedback could be a result of the above-discussed negative relation between the 2 age groups on a spatial scale. In years with high numbers of adults few areas will be left with low adult densities. As a consequence of the spacing-out phenomenon, all suitable places will be occupied. Only where environmental conditions are less suitable for adults, as in the higher intertidal zones (Fig. 6), may greater juvenile densities regularly occur: the so-called nursery areas (Farke et al. 1979). Such high coastal zones with generally large densities of juvenile lugworms are present only where the coastal sediments are not too silty. That is why such nursery zones are lacking along most of the mainland coast of the Wadden Sea. Here, juveniles have to settle further from the shore, where the sediment is sandier, but the level is also sufficiently low to be suitable for adult lugworms. In such areas, adults generally leave little space for juveniles and high juvenile densities appear to be exceptional and restricted to areas where densities of adults happen to be temporarily low. As these areas are not distinct by any other characteristic and their location changes from year to year (compare Fig. 7d with Fig. 7e), the occasionally high densities of juveniles in such areas appear to be caused solely by temporarily low densities of adults. The locally high 
densities of juveniles observed on Balgzand in 1991 (Fig. $7 \mathrm{C}$, d) were higher than in any other year of the 1970 to 1993 period. In early 1991, adult densities were exceptionally low as a consequence of an abnormally high mortality rate in 1990-91 (Beukema 1993a).

The initial response of the juvenile recruitment to the relatively low adult densities in 1991 was rather extreme, resulting in mean densities of juveniles on Balgzand amounting to more than $50 \mathrm{~m}^{-2}$ in summer 1991. Most of these juveniles disappeared before March 1992 by migration in winter (Fig. 10a, b), leaving an average of about $15 \mathrm{~m}^{-2}$ (Fig. 11a). This abnormally strong decline of juvenile density occurred in the year with an exceptionally high density in summer (Fig. 11a). A stronger tendency to start long-distance migration at higher juvenile densities may be another feed-back mechanism to keep densities within certain limits.

In summary, the following observed mechanisms will contribute to evenness and stability of lugworm populations: (1) spacing-out of adult populations (promoting evenness), (2) suppression of numbers of juveniles wherever and whenever adults are numerous (effectively reducing variability in density both from place to place and from year to year), and (3) stimulation of migration in small juveniles when these are crowded and remain small (reducing again variability in density both in space and in time).

In several respects, the complex recruitment strategy in Arenica marina shows similarity with that exhibited by the bivalve Macoma balthica in the same area (Beukema 1993b). In both species most juveniles grow up in refugia at higher intertidal levels than where most adults live, from where they migrate in winter to lower and more offshore areas where adults thrive. Both species are widespread on the tidal flats of the Wadden Sea (Beukema 1976, Dankers \& Beukema 1983 ) and their populations are more stable than those of other macrozoobenthic species in the Wadden Sea (Beukema et al. 1993: Figs. 3 \& 4). Apparently, a strategy of juveniles and adults living mostly in separate habitats, including a relatively late life stage during which a secondary redistribution takes place, is highly successful.

Acknowledgements. We thank Wim de Bruin and Jaap Zuidewind for their assistance. We also thank Ewout Adriaans, skipper of the RV 'Griend', and the crew of the RV 'Navicula' for guiding us to various tidal-flat areas of the Wadden Sea. We are very grateful to the Royal Swedish Academy of Sciences for providing us laboratory facilities and accommodation at Kristineberg Marine Biological Station (Director: Jarl-Ove Strömberg) and to Rutger Rosenberg, Leif Pihl and all others at Kristineberg who were always very kind and helpful. Financial support was given by the Royal Dutch Academy of Sciences (KNAW).

\section{LITERATURE CITED}

Beukema, J. J. (1974). Seasonal changes in the biomass of the macro-benthos of a tidal flat area in the Dutch Wadden Sea. Neth. J. Sea Res. 8: 94-107

Beukema, J. J. (1976). Biomass and species richness of the macrobenthic animals living on tidal flats in the western part of the Wadden Sea. Neth. J. Sea Res. 10: 236-261

Beukema, J. J. (1988). An evaluation of the ABC-method (abundance/biomass comparison) as applied to macrozoobenthic communities living on tidal flats in the Dutch Wadden Sea. Mar. Biol. 99; 425-433

Beukema, J. J. (1991). Changes in composition of bottom fauna of a tidal-flat area during a period of eutrophication. Mar. Biol. 111: 293-301

Beukema, J. J. (1992). Long-term and recent changes in the benthic macrofauna living on tidal flats in the western part of the Wadden Sea. Neth. Inst. Sea Res. Publ. Ser. 20: $135-141$

Beukema, J. J. (1993a). Increased mortality in alternative bivalve prey during a period when the tidal flats of the Dutch Wadden Sea were devoid of mussels. Neth. J. Sea Res. 31: 395-406

Beukema, J. J. (1993b). Successive changes in distribution patterns as an adaptive strategy in the bivalve Macoma balthica (L.) in the Wadden Sea. Helgoländer Meeresunters. 47: $287-304$

Beukema, J. J., Cadée, G. C. (1986). Zoobenthos responses to eutrophication of the Dutch Wadden Sea. Ophelia 26: $55-64$

Beukema, J. J., Cadée, G. C., Hummel, H. (1983). Differential variability in time and space of numbers in suspension and deposit feeding benthic species in a tidal flat area. Oceanol. Acta No. Sp.: 21-25

Beukema, J. J., de Vlas, J. (1979). Population parameters of the lugworm, Arenicola marina living on tidal flats in the Dutch Wadden Sea. Neth. J. Sea Res. 13: 331-353

Beukema, J. J., Essink, K., Michaelis, H., Zwarts, L. (1993). Year-to-year variability in the biomass of macrozoobenthic animals on tidal flats of the Wadden Sea: how predictable is this food source for birds? Neth. J. Sea Res. 31: 319-330

Brey, T. (1989). Der Einfluss physikalischer und biologischer Faktoren auf Struktur und Dynamik der sublitoralen Macoma-Gemeinschaft der Kieler Bucht. Ber. Inst. Meereskde Kiel 186: 123-175

Cadée, G. C. (1976). Sediment reworking by Arenicola marina on tidal flats in the Dutch Wadden Sea. Neth. J. Sea Res. 10: 440-460

Cazaux, C. (1967). Évolution d'une population d'Arenicola marina (L.) à Arcachon. Cycle annuel - période de réproduction. Act Soc. Linn. Bordeaux, Série A, 103(15): $3-18$

Dankers, N., Beukema, J. J. (1983). Distributional patterns of macrozoobenthic species in relation to some environmental factors. In: Wolff, W. J. (ed.) Ecology of the Wadden Sea, Vol. 1, part 4. Balkema, Rotterdam, p. 69-103

De Wilde, P. A. W. J., Berghuis, E. M. (1979). Laboratory experiments on growth of juvenile lugworms, Arenicola marina. Neth. J. Sea Res. 13: 487-502

Dörjes, J., Michaelis, H., Rhode, B. (1986). Long-term studies of macrozoobenthos in intertidal and shallow subtidal habitats near the island of Norderney (East Frisian coast, Germany). Hydrobiologia 142: 217-232

Farke, H., Berghuis, E. M. (1979a). Spawning, larval development and migration behaviour of Arenicola marina in the laboratory. Neth. J. Sea Res. 13: 512-528

Farke, H., Berghuis, E. M. (1979b). Spawning, larval develop- 
ment and migration of Arenicola marina under field conditions in the western Wadden Sea. Neth. J. Sea Res. 13: $529-535$

Farke, H., de Wilde, P. A. W. J., Berghuis, E. M. (1979). Distribution of juvenile and adult Arenicola marina on a tidal mud flat and the importance of nearshore areas for recruitment. Neth. J. Sea Res. 13: 354-361

Flach, E. C. (1992). Disturbance of benthic infauna by sediment-reworking activities of the lugworm Arenicola marina. Neth. J. Sea Res. 30: 81-89

Flach, E. C. (1993). The distribution of the amphipod Corophium arenarium in the Dutch Wadden Sea: relationships with sediment composition and the presence of cockles and lugworms. Neth. J. Sea Res. 31: 281-290

Flach, E. C., de Bruin, W. (1993). Effects of Arenicola marina and Cerastoderma edule on distribution, abundance and population structure of Corophium volutator in Gullmarsfjorden, western Sweden. Sarsia 78: 105-118

Flach, E. C., de Bruin, W. (1994). The activity of cockles, Cerastoderma edule (L.), and lugworms, Arenicola marina L., make Corophium volutator (Pallas) more vulnerable to epibenthic predators: a case of interaction modification. J. exp. mar. Biol. Ecol. (in press)

Levinton, J. (1972). Stability and trophic structure in deposit-

This article was submitted to the editor feeding and suspension-feeding communities. Am. Nat. 106: $472-486$

Pollack, H. (1979). Populationsdynamik, Produktivität und Energiehaushalt des Wattwurms Arenicola marina (Annelida, Polychàeta). Helgoländer wiss. Meeresunters. 32: $313-358$

Reise, K. (1985). Tidal flat ecology. An experimental approach to species interactions. Ecological studies 54. SpringerVerlag, Berlin, p. 1-199

Rijken, M. (1979). Food and food uptake in Arenicola manina. Neth. J. Sea Res. 13: 406-421

Smidt, E. L. B. (1951). Animal production in the Danish Wadden Sea. Meddr Kommn Danm. Fisk.- og Havsunders. (Ser. Fiskeri) 11: 1-151

Thamdrup, H. M. (1935). Beiträge zur Ökologie der Wattenfauna auf experimenteller Grundlage. Meddr Kommn Danm. Fisk. - og Havsunders. (Ser. Fiskeri) 10: 1-125

Van den Heiligenberg, T. (1987). Effects of mechanical and manuel harvesting of lugworms Arenicola marina L. on the benthic fauna of tidal flats in the Dutch Wadden Sea. Biol. Conserv. 39: 165-177

Werner, B. (1956). Über die Winterwanderung von Arenicola marina L. (Polychaeta sedentaria). Helgoländer wiss. Meeresunters. 5: 353-378

Manuscript first received: April 5, 1994

Revised version accepted: September 9, 1994 